УДК 37.016:62/65

DOI:

Оксана Степанчак, вчитель обслуговуючих видів праці загальноосвітньої школи I - III ступенів № 17 м. Дрогобич

\title{
ПРОЕКТНО-ТЕХНОЛОГІЧНА ДІЯЛЬНІСТЬ НА УРОКАХ ТРУДОВОГО НАВЧАННЯ (на прикладі виготовлення поясного виробу: спідниці)
}

У статті проаналізовано мету та завдання проектно-технологічної діяльності школярів на уроках трудового навчання. Розглянуто типологію навчальних проектів у педагогічній науці, визначено функиії творчих проектів на заняттях з трудового навчання, охарактеризовано вимоги до вибору тематики проектів. Вказано на структуру проектно-технологічної діяльності. На прикладі проекту "Виготовлення спідниці"” охарактеризовано иляхи реалізаиії проектно-технологічної діяльності на уроиі трудового навчання. Доведено, щу впровадження в освітній процес, зокрема й з трудового навчання, методу проектів створює можливості для підвищення якості навчання та різнобічного розвитку особистості учня.

Ключові слова: проект; метод проектів; проектно-технологічна діяльність; урок трудового навчання; інформаційно-комунікаційні технології.

Jim. 7.

Oksana Stepanchak, Teacher of Servicing Kinds of Work Secondary General Education School № 17, Drohobych

\section{DESIGN AND TECHNOLOGICAL ACTIVITY AT THE LABOUR TRAINING LESSONS (on the example of the manufacture of a waistband, a skirt)}

The article analyzes the purpose and tasks of the design and technological activity of schoolchildren at the labour training lessons. It is stated that in response to the challenges of the time, the updated labour training curriculum for students in grades from 5 to 9 is aimed at diversifying personal development through the involvement of students in design and technology activities as an important means of development, learning and education. The purpose of the article is to substantiate the advantages of the use of design and technological activity at the labour training lessons.

It is established that the purpose of the design and technological activity is to promote the independent formation of general labor and special knowledge, as well as proficiency and skills embodied in the final competitive product. The design and technological activity of the students is directed towards the creation of projects. In the process of working on the project, conditions are created for the development of initiative, teamwork skills, collaboration, the ability to think logically, finding the necessary information, planning activities, self-education, formation of communication skills, etc. The schoolchildren learn to find and solve a variety of problems. In order to do this, they carry out a number of operations, namely selecting an object, developing its design at the level of an idea and in the form of a document, assessing technical and technological capabilities, economic, environmental and social feasibility, designing the project and monitoring its implementation.

The typology of educational projects in pedagogical science (research, search, role, applied, study-oriented, etc.) is considered, the functions of creative projects at the labour training lessons are defined, the requirements for the choice of project topics (social and psychological) are characterized. The structure of design and technological activity (preparatory, technological, final stages) is indicated. The ways of realization of design and technological activity at the labour training lessons are described on the example of the project of skirt making. It is proved that implementation of the method of projects in the educational process (in the field of vocational education in particular) creates opportunities for improving the quality of learning and the diverse development of the student's personality.

Keywords: a project; a method of projects; design and technological activities; vocational training lesson; information and communication technologies.

П остановка проблеми у загальному вигляді. На сучасному етапі розвитку суспільства перед закладами загальної середньої освіти стоїть завдання формування творчої особистості, здатної самостійно творити життєвий проект, ініціативної, підприємливої, активної. Сучасна школа покликана підвищувати інтелектуальний потенціал підростаючого покоління, яке має уміти не лише освоювати, але й творчо використовувати досягнення науково-технічного процесу, виховувати кожного школяра як особистість, здатну власними зусиллями досягнути життєвого успіху.

Саме тому зростає роль проектнотехнологічної діяльності, яка, за правильної організації, здатна сприяти підвищенню інтелектуального та фізичного потенціалу учнів, 
розвитку їхніх компетенцій, стимулювати пізнавальну активність, розвивати творчі здібності.

В контексті зазначеного варто відзначити, що у відповідь на виклики часу оновлена навчальна програма 3 трудового навчання для учнів $5-9$ класів спрямована на різнобічний розвиток особистості завдяки залученню школярів до проектно-технологічної діяльності як важливого засобу розвитку, навчання та виховання.

Аналіз останніх досліджень і публікацій. Проблема проектно-технологічної діяльності на уроках трудового навчання активно досліджується в науковому дискурсі.

Зокрема, відомий вітчизняний вчений О. Коберник стверджує, що проектнотехнологічна система трудового навчання прийшла на зміну конструкторсько-технологічній. Вона передбачає включення школярів до творчої діяльності за допомогою систем конструкторських і технологічних завдань. На переконання автора, проектно-технологічна діяльність - це обгрунтована і наперед спланована творча навчально-трудова діяльність, що передбачає обгрунтування, планування, розробку конструкції, технології, виготовлення та реалізацію об'єктів проектування. Завдяки участі в такій діяльності в школярів формується система творчоінтелектуальних та предметно-перетворювальних знань та вмінь [4, 88].

Натомість, на думку В. Сидоренка, проектнотехнологічна діяльність школярів $€$ інтегративним видом діяльності, метою якої є створення виробів чи послуг, які мають об'єктивну або суб'єктивну новизну і особисту чи суспільну значущість [5, 2].

Як одну 3 найбільш продуктивних та інтенсивних методик, що забезпечує досягнення високих результатів навченості й освіченості особистості, називає В. Соловей проектне навчання. Завдяки проектній методиці уможливлюється переорієнтація освітнього процесу на постановку і самостійне розв'язання школярами пізнавально-комунікативних i дослідницьких задач $[6,483]$.

Вчені досліджують структуру та педагогічний інструментарій проектно-технологічної діяльності, функції вчителя в ії̈ організації тощо. Вважаємо, що не менш важливим є вивчення досвіду практичної діяльності педагогів-практиків із організації проектно-технологічної діяльності школярів на уроках трудового навчання.

Мета статті. На прикладі виготовлення поясного виробу обгрунтувати переваги застосування проектно-технологічної діяльності на уроках трудового навчання.
Виклад основного матеріалу. Проектнотехнологічна діяльність школярів спрямовується на створення проектів. Під проектами ми розуміємо самостійну творчу роботу учнів. Мета проектно-технологічної діяльності - сприяти самостійному формуванню загальнотрудових та спеціальних знань, умінь та навичок, втілених у кінцевий конкурентоздатний продукт. У процесі роботи над проектом створюються умови для розвитку ініціативи, навичок роботи в колективі, співпраці, уміння логічно мислити, пошуку необхідної інформації, планування діяльності, самоосвіти, формування комунікативних навичок тощо.

Школярі вчаться шукати і розв'язувати різноманітні проблеми. Для цього вони здійснюють низку операцій: вибір об'єкта, розробку його конструкції спочатку на рівні ідей, а згодом - у вигляді документа, оцінку технікотехнологічних можливостей, економічної, екологічної і соціальної доцільності, виготовлення проекту та контроль за його виконанням.

У результаті проектно-технологічної діяльності відбувається формування проектно-технологічної компетентності як здатності учня "застосовувати знання, уміння, навички в процесі проектнотехнологічної діяльності для виготовлення виробу (або надання послуги) від творчого задуму до його втілення в готовий продукт (послугу) за обраною технологію" [7].

У педагогічній науці розглядають різні види проектів. Зокрема, Н. Боринець за домінуючою діяльністю виділяє дослідницькі, пошукові, рольові, прикладі, ознайомлювально-орієнтовані тощо проекти. При цьому науковець наголошує: “щодо трудового навчання, то творчі проекти школярів можна назвати “матеріальними”, тому що учні обирають тему проекту..., пов'язану із виготовлення того чи іншого виробу (продукт, послуги), який обов'язково розрахований на подальше практичне застосування" [2, 33].

Творчі проекти на заняттях 3 трудового навчання виконують низку функцій, зокрема:

- навчальну, спрямовану на закріплення i поглиблення політехнічних знань, умінь і навичок учнів;

- розвивальну, що полягає у розвитку психічних процесів, моторики і творчих здібностей;

- виховну, яка передбачає формування таких якостей особистості, як ініціативність, самостійність, акуратність, підприємливість тощо.

Обираючи тематику проектів учитель трудового навчання має дотримуватися таких вимог:

- соціальних (суспільно корисна і особистісна 
значущість, творча спрямованість, врахування регіональних особливостей);

- психолого-фізіологічних (відповідність рівню підготовки школярів, їхнім індивідуальним та віковим особливостям, врахування інтересів дітей, можливостей і зацікавлень вчителя трудового навчання);

- технолого-економічних (відповідність матеріально-технічним умовам навчальних майстерень, політехнічна спрямованість, забезпечення санітарно-гігієнічних і безпечних умов праці) тощо.

Згідно з навчальною програмою з трудового навчання, затвердженою МОН України 07.06.2017 р. за № 804, у 5 - 6 класах учні мають опанувати 6 - 10 проектів, у $7-8$ - від 4 до 6 проектів, у 9 класі - 2 проекти [7].

Очевидно, що навчання роботи над творчими проектами має бути поступовим. Спочатку учням варто пропонувати короткочасні проекти, для виконання яких достатньо одного уроку. Згодом проекти можуть ускладнюватися та бути більш тривалими у часі.

Робота над проектом передбачає самостійну (парну, групову) діяльність школярів над певним завданням під керівництвом учителя. Учні вчаться працювати з інформаційними джерелами, відшуковувати інформацію, що торкається тематики проекту, та аналізувати іiі, застосовувати методи проектної діяльності, здійснювати планування технологічного процесу із виготовлення виробу та обирати необхідні матеріали й інструменти. Доцільно також навчати школярів проводити елементарне економічне обгрунтування виробу ще до початку його виготовлення. Відтак у процесі виконання проекту створюються умови для розвитку в учнів технічного і технологічного мислення, економічної свідомості тощо.

Логіка структурування діяльності при виконанні проекту має відповідати загальній структурі проектування, яка охоплює три етапи: підготовчий (розробка проектного замислу, що включає аналіз ситуації, аналіз проблеми, ціле покладання, планування), технологічний (реалізація проектного замислу, яка передбачає виконання запланованих дій), заключний (оцінка результатів проекту) $[3,11]$.

Н. Боринець ще глибше конкретизує завдання, які стоять перед учнями, на кожному з етапів виконання проекту.

Вчена переконана, що на першому етапі, який вона назвала організаційно-підготовчим, школярі мають обрати тему проекту із запропонованого вчителем списку, або вигадати свою; обгрунтувати вибір теми; розробити критерії майбутнього виробу; визначити обсяг знань та вмінь, що потрібний для втілення задуму. Окрім цього, учні працюють над пошуком та опрацюванням літератури, шукають аналоги задуманого виробу, аналізують їх за низкою критеріїв, серед яких - призначення, розмір, колір, умови використання, матеріали, вартість, естетичність, час, необхідний для виконання. Завершується робота на цьому етапі задумкою власних конструкцій виробу, що втілюються у ескізних малюнках, конструкторсько-технологічній документації (креслення, схеми, художнє конструювання); визначенні найдоцільнішої технології виготовлення виробу, здійснення добору матеріалів та інструментів, плануванні організації робочого місця, виконанні екологічних, економічних та міні-маркетингових досліджень.

На другому (технологічному) відбувається виготовлення виробу. Для цього учень виконує технологічні операції, за необхідності коригує власну діяльність, здійснює самоконтроль і самооцінку своєї діяльності, а також оцінювання якості виготовленого виробу.

На заключному етапі відбувається коригування (за необхідності) виконаного виробу відповідно до заздалегідь запланованого, коригування технології виготовлення виробу (за необхідності), остаточний контроль і випробування проекту. На цьому етапі учні оформлюють портфоліо проекту (проектної папки), а також готуються до захисту проекту. Відбувається підбиття підсумків роботи над проектом (чи досягли поставленої мети, які витрати часу, зусиль, матеріалів тощо, який результат праці, його практичне значення). Захисти проекту можуть відбуватися у різних формах: виставки учнівських робіт, учнівські ярмарки, демонстрування моделей одягу тощо [1, $11-12]$.

О. Коберник вважає, що структура проектнотехнологічної діяльності має включати чотири етапи: організаційно-підготовчий, конструкторський, технологічний та заключний $[4,89]$.

Відповідно до навчальної програми з трудового навчання для 5 - 9 класів орієнтовний перелік проектно-технологічної діяльності учнів $7-8$ класів містить виготовлення поясного швейного виробу. Принагідно зазначимо, що до таких виробів належать спідниці, штани, шорти, які можуть бути складовою костюма або самостійним видом одягу.

У практичній діяльності вчителя трудового навчання виконуємо з учнями 8 класу проект “Виготовлення спідниці".

Підготовка та реалізація такого проекту 
відповідають низці вимог. Насамперед розробка проекту здійснюється за ініціативою учнів, проект орієнтується на розв'язання конкретної проблеми, $\epsilon$ реалістичним, а робота над ним носить дослідницький характер. Хоча проект завчасно планується, допускається гнучкість та внесення коректив у хід виконання.

Незважаючи на те, що під час проектної діяльності зростає роль самостійної роботи учнів, вчитель також $\epsilon$ активним учасником, допомагаючи школярам шукати необхідну інформацію або жє єї джерелом, координує процес роботи, мотивує виконавців, підтримує зворотній зв'язок для успішної реалізації проекту.

На підготовчому етапі роботи над проектом відбувається зацікавлення учнів та мотивування на його виконання. Для актуалізації опорних знань школярам пропонується пригадати, що вони вже навчилися моделювати та повторити креслення спідниці.

Далі педагог або школярі (за умови попередньої підготовки) повідомляють історію виникнення і розвитку спідниці, ознайомлюють 3 видами спідниць, розповідають про критерії вибору спідниці відповідно до типу фігури. У вигляді презентації Power Point демонструються моделі сучасних спідниць. Здійснюється також інструктаж щодо техніки безпеки і основних вимог до виробу.

Відтак учні обгрунтовують вибір спідниці на основі особистих потреб та формують вимоги до обраного виробу.

На наступному, технологічному, етапі здійснюються операції, передбачені технологічним процесом. Виготовлення виробу здійснюється у строгій послідовності операцій, вказаних у технологічній карті чи технологічному процесі.

Учням пропонується така послідовність виготовлення спідниці:

1) зняття мірок;

2) конструювання спідниці;

3) виготовлення виробу:

а) виготовлення викрійки спідниці;

б) підготовка тканини i виконання розкроювання спідниці;

в) підготовка деталей крою до обробки і спідниці до примірки;

г) примірка спідниці і виправлення дефектів, якщо вони виникли;

д) обробка бокових зрізів і виточок;

е) обробка шліци в середньому шві задньої половини спідниці;

є) обробка застібки у середньому шві задньої половини спідниці тасьмою-блискавкою;

ж) обробка верхнього зрізу спідниці;
3) обробка поясу і пришивання декоративної застібки;

и) обробка нижнього зрізу спідниці;

i) оздоблення та остаточна обробка спідниці;

i) перевірка якості готового виробу.

На заключному етапі відбувається захист проектів. Кожен з учнів готує доповідь і захищає свою роботу перед класом. На захист подаються: виріб, обгрунтування проекту, технічна документація, рекламний проспект і економічний розрахунок. За можливості на цьому етапі використовуються інформаційно-комунікаційні технології. Наприклад, обгрунтування проекту можна виконати в текстовому редакторі, економічні розрахунки - в електронних таблицях. Текстові і графічні редактори можна використати для виготовлення рекламних проспектів тощо.

На цьому етапі учні мають можливість поставити запитання один одному стосовно виготовлених виробів. Після захисту вчитель оцінює усі роботи і підбиває підсумки уроку.

Логічним завершенням виконання проекту може стати показ виготовлених моделей перед учнями школи та батьками.

Отже, аналіз наукової літератури та досвід практичної діяльності засвідчує, що впровадження в освітній процес, зокрема й з трудового навчання, методу проектів створює можливості для підвищення якості навчання. Особливість цього методу полягає у самостійному пошуку і аналізі необхідної інформації, виготовленні виробу, оцінюванні і публічному захисті проекту. Його використання сприяє розвитку самостійності школярів, вчить об'єктивно оцінювати власну діяльність, розвиває навички співпраці та комунікації, організаційні і рефлексивні здібності.

Перспективами подальших досліджень $є$ розробка банку проектів для учнів загальноосвітньої школи, пошук шляхів удосконалення технологічної підготовки вчителів трудового навчання тощо.

\section{ЛІТЕРАТУРА}

1. Боринець Н. Метод проектів у викладанні трудового навчання. Трудове навчання. 2011. № 9. С. $8-15$.

2. Боринець Н. Проектно-технологічна діяльність учнів і вчителів трудового навчання. Освітологічний дискурс. 2010. № 1. С. $32-41$.

3. Голуб Г.Б., Перелыгина Е.А., Чуракова О.В. Метод проектов - технология компетентностноориентрированного образования / под ред. Е.Я. Когана. Самара, 2006. 176 с.

4. Коберник О. Еволюція систем трудового навчання. Науковиц часопис НПУ імені 
М.П. Драгоманова. Серія 13: проблеми трудової та професійної підготовки. 2010. Вип. 6. С. $84-90$.

5. Сидоренко В. Проектно-технологічний підхід як основа оновлення змісту трудового навчання школярів. Трудова підготовка в закладах освіти. 2004. № 1. С. 2 - 4.

6. Соловей В. Сутність технологічної підготовки майбутнього вчителя трудового навчання. Сучасні інформаційні технологї та інновачійні методи навчання у підготовці фахівиів: методологія, теорія, досвід, проблеми : зб. наук. пр. К. - Вінниця, 2008. Вип. 19. С. $480-485$.

7. Трудове навчання. 5 - 9 класи. Програма для загальноосвітніх навчальних закладів. URL : https://imzo.gov.ua/osvita/zagalno-serednya-osvita-2/ navchalni-prohramy-5-9-klasy-naskrizni-zmistoviliniji/trudove-navchannya-tehnichni-vydy-pratsinaskrizni-zmistovi-liniji/

\section{REFERENCES}

1. Borynecz, N. (2011). Metod proektiv u vykladanni trudovogo navchannya [Method of projects in the teaching of labor education]. Labor education. No. 9, pp. 8 - 15. [in Ukrainian].

2. Borynecz, N. (2010). Proektno-texnologichna diyalnist uchniv i vsyteliv trudovogo navchannya [Design and technological activity of students and teachers of labor education]. Educological Discourse. No. 1, pp. 32 - 41. [in Ukrainian].

3. Golub, G.B., Perelygina, E.A. \& Churakova, O.V.
(2006). Metod proektov - tehnologija kompetentnostno-orientrirovannogo obrazovanija [Project Method - Competency-Based Education Technology]. Samara, 176 p. [in Russian].

4. Kobernyk, O. (2010). Evolyuciya system trudovogo navchannya [Evolution of labor education systems]. Scientific journal of NPU. Drahomanov. Series 13: Challenges to Work and Career Training. Vol. 6, pp. $84-90$. [in Ukrainian].

5. Sydorenko, V. (2004). Proektno-texnologichnyj pidxid yak osnova onovlennya zmistu trudovogo navchannya shkolyariv [Project-technological approach as a basis for updating the content of labor education of students]. Labour training in educational institutions, No. 1, pp. $2-4$. [in Ukrainian].

6. Solovej, V. (2008). Sutnist texnologichnoyi pidgotovky majbutnogo vchytelya trudovogo navchannya [Essence of technological preparation of the future teacher of labor training]. Modern information technologies and innovative methods of training in the training of specialists: methodology, theory, experience, problems: a collection of scientific works. K. - Vinnycya. Vol. 19, pp. 480-485. [in Ukrainian].

7. Trudove navchannya. 5 - 9 klasy. (2017). [Labour education. Grades 5 -9]. The program for secondary schools. Available at: https://imzo.gov.ua/ osvita/zagalno-serednya-osvita-2/navchalniprohramy-5-9-klasy-naskrizni-zmistovi-liniji/trudovenavchannya-tehnichni-vydy-pratsi-naskrizni-zmistoviliniji/ [in Ukrainian].

Стаття надійшла до редакції 19.08.2019

\section{}

"Здобувайте знання, теоретичне й прақтичне, гартуйте свою волю, виробляйте себе на серйозних свідомих $i$ статечних мужів, повних любові до свого народу $i$ здібних виявляти ту любов не потоқами шумних браз, а невтомною, тихою пращею”.

Іван Франко видатний уқрайнський поет, письменник, пробеесор

“Вчителі, яқим діти зобов’язані вихованням, поважаніші, ніж батьқи: одні дарують нам тільки життя, а інші-добре життя”.

Apicmomess

давньогрецький вчений-енциклопедист, ббілособ

“Найбільша иінність для людини - ие ї̈ власне виховання".

Тригорій Сқоворода

уқраїнський поет, ббілософб

\section{G58080}

